\title{
Root Engineering for Self-Irrigation that Exploits Soil Depth Dimension for Carbon Sequestration
}

\author{
Final Report
}

For Period August 27, 2001 - February 26, 2002

by

Edward G. Gatliff

Applied Natural Sciences, Inc

4129 Tonya Trail, Hamilton, $\mathrm{OH} 45011$

and

M. Cristina Negri

Argonne National Laboratory

9700 S. Cass Avenue, Argonne, IL 60439

Notice

This report was prepared as an account of work sponsored by the United States Government. Neither the United States nor the United States Department of Energy, nor any of their employees, nor any of their awardees, subcontractors, or their employees, makes any warranty, express or implied, or assumes any legal liability or responsibility for the accuracy, completeness, or usefulness of any information, apparatus, product or process disclosed or represents that its use would not infringe privately-owned rights.

The submitted manuscript has been created by the University of
Chicago as Operator of Argonne National Laboratory ("Argonne")
under Contract No. W-31-109-ENG-38 with the U.S. Department of
Energy. The U.S. Government retains for itself, and others acting on its
behalf, a paid-up, nonexclusive, irrevocable worldwide license in said
article to reproduce, prepare derivative works, distribute copies to the
public, and perform publicly and display publicly, by or on behalf of the
Government.

May 28, 2002

Prepared for

THE U.S. DEPARTMENT OF ENERGY

Under Award No. DE-FG02-01ER83146 


\section{Table of Contents}

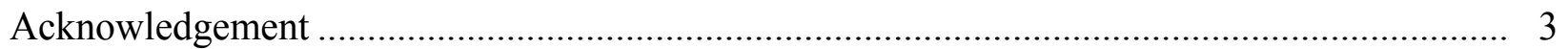

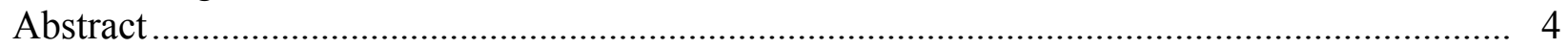

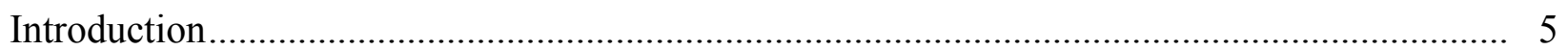

Objectives of Phase I ................................................................................................ 8

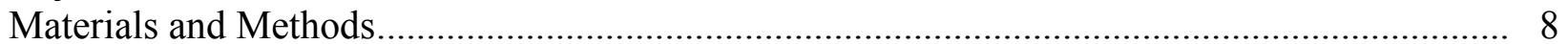

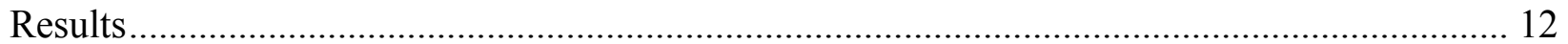

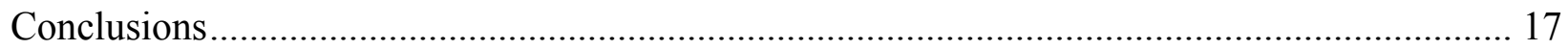

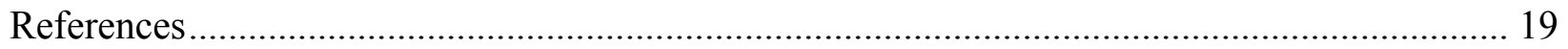

Fig. 1 Diagram of TreeWell ${ }^{8}$ root-engineering method. .................................................. 20

Fig. 2 Mean root density inside the TreeWell® casing, outside the casing, and at $0.3 \mathrm{~m}$ of a non-cased tree, Argonne site.................................................... 21

Fig. 3 Mean root density in non cased poplars at $0.3,1$, and $3 \mathrm{~m}$ from tree center. Mean of three replicants, Cantrall site ....................................................................... 22

Fig. 4 Mean root density in the fill material inside the TreeMediation ${ }^{\circledR}$ casing and outside. Data are mean of three replications, Cranbury site ................................ 23

Fig. 5 Mean root length inside and outside the TreeMediation ${ }^{\circledR}$ casing. Data are mean of three replications, Cranbury site................................................... 24

Fig. 6 Mean root length distribution in three diameter classes in the fill inside the TreeMediation ${ }^{\circledR}$ casing, Cranbury site.

Fig. 7 Cross sections of a shallow and deep root of hybrid poplar showing the Periphery of the secondary xylem cylinder on the right and the secondary phloem tissues on the left.

Fig.8 Cross sections of a shallow and deep root of hybrid poplar showing a portion of the aerenchyma tissue of each.

Fig. 9 Aerenchyma tissue in cross sections of shallow and deep roots of hybrid poplar showing amyloplasts inside the cells

Appendix A. Statistical Analysis Reports 


\section{Acknowledgement}

The authors would like to express their sincere thanks to Drs. Julie Jastrow, R. Michael Miller, and Roser Matamala of Argonne National Laboratory and Terrestrial Ecology Group for their help and support in the analysis of root samples. 


\begin{abstract}
A comprehensive carbon management program to sequester excess $\mathrm{CO}_{2}$ includes the maximization of the carbon sink potential of the terrestrial ecosystem.

The establishment of sustainable vegetation on semi-arid or damaged land is necessary to increase the carbon inventory in the terrestrial ecosystem, as it is increasing the depth of the soil carbon sink. The availability of water for sustained growth at acceptable costs, when or where precipitation is too scarce or unpredictable, may, however, significantly affect the cost and sustainability of the revegetation efforts. We tested an innovative technology that enables the establishment of "plantations" that are independent of erratic water supplies or irrigation by developing deep root systems that tap into deeper groundwater. Applied Natural Sciences' (ANS) patented technologies (TreeMediation $\AA$ and TreeWell $\AA$ systems) overcome soil conditions unfavorable to deep rooting and "engineer" the growth of phreatophytic tree roots into soil to reliably reach the groundwater. Carbon sinks can then be increased by increasing rooting depths and especially by enabling vegetative growth altogether.
\end{abstract}

We collected soil cores from three phytoremediation sites where these technologies have been previously deployed. From these, we developed detailed information on root density and soil conditions at increasing depths to estimate $\mathrm{C}$ gains. The largest $\mathrm{C}$ gains were found when these technologies are used to control desertification. In these cases, significant gross $\mathrm{C}$ gains (at least between 4 and 6 tons/ha per year) can be envisioned.

Other indirect benefits include resource recycling, pollution prevention, remediation, creating agricultural diversity and innovation in fruit and other tree crop and hardwood management. 


\section{Introduction}

A comprehensive carbon management program to sequester excess $\mathrm{CO}_{2}$ includes the maximization of the carbon sink potential of the terrestrial ecosystem. A number of strategies have been identified to increase below ground carbon (Office of Science, U.S. DOE):

- Increase the depth of soil carbon;

- Increase the density of carbon (organic and/or inorganic) in the soil;

- Increase the mass and /or depth of roots;

- Decrease the decomposition rate of soil carbon.

Overall, the establishment or reestablishment of vegetation in a sustainable fashion on marginal, semi-arid, or damaged land is considered a necessary approach to increase both the above- and below-ground carbon inventory in the terrestrial ecosystem. Increasing vegetation in marginal, semi-arid, and/or disturbed land is, however, a significant task since the availability of water at acceptable costs, when precipitation is too scarce or unpredictable, may significantly affect the cost and sustainability of the revegetation efforts. Vegetating marginal land has however the potential for the sequestration of 1.5 to $2.5 \mathrm{Pg} / \mathrm{yr}$ worldwide, of which $0.9-1.4 \mathrm{Pg} \mathrm{C}$ per year with the control of land erosion alone (R. Lal, 2000). Techniques that may improve the rate of success and control the costs of revegetating marginal or arid land need to be developed. One strategy is to intervene with small "plantations" of vegetation that is independent on erratic water supplies or irrigation. This initial plantation would then serve as a windbreak and favor the establishment of additional, native vegetation in its surroundings. To be successful, plants need to develop deep root systems that can tap into groundwater resources and not rely solely on precipitation.

Currently, most of the rooting is expected to occur in the first meter or 2 below ground surface, and, therefore, this is the soil layer that is currently considered the $\mathrm{C}$ sink in the terrestrial ecosystem. In fact, as Canadell et al. report (1996), the real contribution of rooting deeper than $2 \mathrm{~m}$ to carbon and nutrient cycles world wide, is probably underestimated. As a consequence, root growth, decay, and decomposition at depths below $2 \mathrm{~m}$ is largely unexplored and very little is understood about the biological processes (carbon fixation, decomposition, and mineralization) that are associated with deep root growth. Since root growth may increase water fluxes in the soil profile (the hydraulic lift phenomenon may be one of the mechanisms), and in turn influence nutrient and carbon cycles, it is of fundamental importance to understand how to maximize root development at depths, how the growth of these roots influences the development of a deep-living microbial community, and how both activities influence the overall rates of carbon fixation (into organic and inorganic sinks) and respiration.

Increasing the depth of rooting is a plausible strategy in itself to increase carbon in the below ground in conditions of both temperate and semi-arid climates:

- In temperate climates, surface soils can be relatively rich in organic matter. Rooting in this soil layer may increase $\mathrm{C}$ sequestration in roots but also enhance microbial respiration and rapid mineralization of the existing organic matter. Rooting at depths would allow for the development on new carbonrich roots and rhizosphere activity in a substrate that is less plentiful of organic matter and oxygen; therefore, less likely to push the $\mathrm{C}$ balance 
towards the "loss" side. In addition, calcium and magnesium-rich minerals in the deeper subsoil and groundwater may efficiently trap the $\mathrm{CO}_{2}$ that is respired by the deep roots and associated rhizosphere organisms at those depths as calcium and magnesium carbonates. Lower temperatures such as those associated with deeper subsoil are also expected to decrease microbial metabolism.

- In semi-arid climates, rooting to groundwater would provide the plants with the necessary access to water, independent of scarce and/or erratic precipitation, and thus allow a higher likelihood of success and selfsustainability of the newly developing vegetation. A windbreak with such self-sustainability could be the starting point for protection from wind erosion and the generation of a localized microclimate of better growth conditions, with subsequent establishment of additional adventitious vegetation. This consideration should gain even more significance if the prediction holds true that climate change will bring more severe and unpredictable weather patterns, with more erratic precipitation patterns even in areas where this is not a problem today.

Phreatophytes are upland plants (which belong to a variety of species and genera and are found in most climatic regions including arid lands) that have the capability, under the proper conditions, of extending their root systems to deeper soil horizons in search of water. While the definition of a phreatophyte is somewhat loose, roots of various phreatophytes have been shown to extend naturally from 4 to over $15 \mathrm{~m}$ (up to $53 \mathrm{~m}$ ) into the soil profile (Waisel et al. 1996). Poplars, willows, mesquite, tamarix, and alfalfa are examples of phreatophytes.

It is well established that phreatophytic roots are capable of exploiting deep-water sources during drought periods. As they do not depend exclusively on precipitation water, these plants are better equipped than others to survive drought and alternating cycles of drought and wet conditions. Phreatophyte rooting patterns are, however, consistent with energy conservation principles, in the sense that deep-rooting strategies are costly for the plant and will not be activated unless there is a specific need for it.

ANS has developed and patented technologies (TreeMediation ${ }^{\circledR}$ and TreeWell ${ }^{\circledR}$ systems (see drawing of Argonne TreeWell ${ }^{\circledR}$ Installation in Figure 1) to overcome soil conditions unfavorable to deep rooting or complex stratigraphies and "engineer" the growth of phreatophytic tree roots into soil to (1) reliably reach the groundwater, typically up to $40 \mathrm{ft}$, and (2), direct the root growth to a particular aquifer of interest while excluding other water sources. In a sense, ANS' technologies activate the deep rooting mechanisms, genetically intrinsic in phreatophytes, in soils where natural growth would not because of energy conservation. While these technologies are currently focused on the treatment of contaminated groundwater (phytoremediation), they could also be very powerful tools in creating self-sustainable (self-irrigating) revegetation techniques for areas where precipitation is either too scarce or unpredictable for appreciable plant growth, with direct and indirect gains in carbon sequestration. Phase I of this SBIR Grant focused on gathering the initial information to assess whether these technologies might be effective in increasing the belowground carbon storage potential. Since the performance of these systems for phytoremediation is currently monitored by determining 
groundwater fluctuations and chemistry and aboveground plant tissue analysis, our work focused on determining root growth and density in these systems.

As part of the Phase I grant, we collected soil cores from three phytoremediation sites (Argonne National Laboratory, IL; Cranbury, NJ; and Cantrall, IL) where these technologies have been previously deployed. From these soil cores we developed detailed information of root density, and soil conditions at increasing depths.

The Argonne site hosts a plantation of 800 poplars and willows specifically planted to reach a rooting depth of approximately $10 \mathrm{~m}(30 \mathrm{ft})$ where contaminated groundwater flows in a complex glacial formation. The young trees were planted in the summer of 1999 to extract the contaminated groundwater from a deep aquifer while bypassing a shallower clean aquifer. The cased trees were backfilled with sand ( 0 to $7 \mathrm{ft}$ below ground surface) and organic matter-rich blend of sand, Dakota peat and topsoil (7-30 ft bgs).

Both the Cantrall and Cranbury sites were established in the 1991-1992 time period and have had many years to develop root systems to the depths of interest for this study. At the Cranbury site, a casing system was utilized to restrict root development near the surface and promote root development to the groundwater $14 \mathrm{ft}$ below ground surface. Cantrall, one of the first sites in the U.S. where phytoremediation was employed, was similarly planted but without the restrictive casing. Without the restrictive casing, root development near the soil surface was not impeded, which appears to have limited significant root development to the groundwater $20 \mathrm{ft}$ below ground surface.

In order to "retrofit" the current deep-rooting technology to make it more cost competitive for the applications sought herein, we tested alternative technologies to enhance the cost vs. benefit ratio for this application, and also examined the potential for utilizing backfill alternatives, such as biosolids and other renewable, refuse-derived materials to maximize the $\mathrm{C}$ sequestration potential and minimize the use of non-renewable peat when backfilling planting holes of the deep rooting trees. By testing alternative methodologies we sought to improve the cost-effectiveness of the technology for larger scale deployments.

Expected benefits from the full development of this technology are both direct and indirect. Direct benefits desired from this approach in the enhancement of $\mathrm{C}$ sequestration are the increase of depth of rooting in temperate areas, and their effectiveness to control desertification at an affordable cost.

Indirect benefits include resource recycling, pollution prevention, remediation, creating agricultural diversity, and, when applied to other woody crops, innovation in fruit and other tree crop and hardwood management 


\section{Objectives of Phase I}

As briefly mentioned before, Phase I focused on the determination of the rooting extent in hybrid poplars grown under different conditions for a number of years at already established phytoremediation field sites, and in bench scale activities. In addition, a root elongation methodology study was performed. However, it was term limited due to the conflict between the period we were funded (August to February) and the availability of trees to use in the study (trees are not available from nurseries until late November). Therefore, these are not as comprehensive as we had envisioned and we must refer to these findings in a general way in some cases.

Specific objectives of Phase I were:

- Investigate rooting density at already existing sites to evaluate $\mathrm{C}$ accumulation in root tissue at depth.

- Determine root morphology changes in roots at different depths.

- Explore alternative, more inexpensive root engineering techniques for revegetation applications.

\section{Materials and Methods}

The activities were divided in three Tasks.

\section{$\underline{\text { Task 1a. Investigate Root Density and Soil Conditions at Existing Sites }}$}

At each site we conducted borings around several trees at several radial distances from the tree centers. As a Geoprobe ${ }^{\circledR}$ could not be successfully utilized to retrieve samples at increasing depths (no sample could be retrieved this way due to the unconsolidated nature of the backfill soil in the TreeMediation ${ }^{\circledR}$ and TreeWell ${ }^{\circledR}$ systems), samples were ultimately collected using a $5 \mathrm{~mm}$ soil probe powered by a hydraulic system that pushed the probe into the soil at a rate that allowed the soil core to enter the probe with a minimum of compaction. This hydraulic probe system was configured to allow continuous sampling at 1 to 1.2 meter intervals to the 4 meter depth utilized for this project.

Field constraints (location, field conditions, and type of planting, plus field sampling difficulties) prevented us from including all possible treatments at every site including the following variables: tree age, location, cased vs. non cased, outside vs. inside casing and distance from tree centers. As it is nearly impossible to obtain multiple soil cores from within a short distance from an individual tree, replicates for the distance from tree "treatment" were obtained sampling several trees at the same distance from center. Treatment samples were collected as follows:

Argonne site (young trees, very difficult terrain prevented boring and collection of a number of cores):

- Cased and non cased trees (casing is $0.60 \mathrm{~m}$ diameter)

- Inside and outside casing (0.3 and $1 \mathrm{~m}$ from the tree center)

- Herbaceous ground cover usually present throughout 
Cantrall site: (older plantation, early technology development did not include a casing)

- Only non cased trees

- Three distances from tree center $(0.3,1$, and $3 \mathrm{~m})$

- Herbaceous ground cover present throughout

Cranbury site (older plantation, casing present throughout and $1 \mathrm{~m}$ diameter):

- Only cased trees

- Outside vs. inside casing $(0.3,1 \mathrm{~m}$ from tree center)

- No herbaceous ground cover present

Boring segments (core) were captured in $5 \mathrm{~cm}$ diameter acetate tubes and logged for location and depth. Each core was divided in 30-cm segments (depths) and each segment was divided in two equal parts. One was subsampled for moisture determination and then used in its entirety for root washing (approximately $200 \mathrm{~g}$ per sample), the other was stored until ready for composting. Composite samples were prepared by merging segments samples of subsequent depth and comparable aspect (as deducted by color using Munsell charts) and sent to a commercial laboratory for chemical analysis. A portion of these composite samples was also used for respiration tests to determine biological activity (Zibilske, 1994). Samples were stored frozen before use and any time they were not being used. Chemical parameters determined included $\mathrm{pH}$, buffer $\mathrm{pH}$, excess lime, soluble salts, \% organic matter, nitrate nitrogen, $\mathrm{P}$, exchangeable $\mathrm{K}, \mathrm{Ca}, \mathrm{Mg}, \mathrm{S}$, and $\mathrm{Fe}$. Standard agronomic analytical methods were used.

Root washing techniques (Oliveira et al. 2000) were used to separate root material from soil in each segment. Washed roots were weighed fresh and after drying at $105^{\circ} \mathrm{C}$. Approx. $200 \mathrm{~g}$. of sample was let to thaw in deionized water in a 3-L pail at ambient temperature. Soil was gently loosened by hand, and then the slurry very gently mixed. When soil particles were settled at the bottom of the pail, the floating roots were retrieved and gently placed on a $0.5 \mathrm{~mm}$ sieve. Roots were then sprayed with a fine mist of DI water until rinse water was clean and then placed on blotting paper. Procedure was repeated on the remaining slurry 4 times so that all visible roots were retrieved. The gently blotted-dry roots were weighed (fresh weight) and stored in root preservative (FAA) until further use. Data were recorded and calculated as $g$ fresh root per g dry soil.

Root samples from the Cranbury site, the oldest site where trees had been planted within a casing, were also used to both investigate root length distribution in diameter classes (scanning), and to conduct light microscopy morphological studies.

Root length and diameter distribution were measured by scanning the rinsed roots after carefully laying them onto a clear, acrylic $9 \times 13$ " tray filled with 0.5 " deionized water. Scanning was conducted at the Argonne Belowground Ecology Laboratory using their specialized WinRhizo equipment and software (Regents Instruments).

For the morphology study, roots collected from the Cranbury soil cores were preserved in FAA (formalin - acetic acid - alcohol) preservative according to Oliveira et al. (2000). Only roots from the shallowest and deepest core segments were examined, assuming these roots would exhibit the extremes in morphological differences, if any, because of the markedly different growing conditions. The number, size, and extent of the interconnected air spaces in the cortex 
(aerenchyma) of the deep and shallow roots was especially studied, since these air spaces are the conduit for air and oxygen for root and (possibly) microbial metabolism deep in the soil. Presence of these also would indicate an adaptive mechanism by which phreatophytes are able to maintain growth into oxygen-poor subsoil.

Shallow $(0-1 \mathrm{~m})$ and deep $(3.5-4 \mathrm{~m})$ root segments about $3.2 \mathrm{~mm}$ in diameter and $2 \mathrm{~cm}$ long were either wrapped in wax-impregnated paper tape or encased in elderberry pith for hand sectioning. Root cross sections were cut with new, sharp, single-edge razor blades using a screw-driven hand microtome. The spongy nature of the aerenchyma tissue in the deep roots made it somewhat more difficult to get uniform hand sections from these roots.

Semi-permanent slides were made by mounting the root sections under a \#1 cover slip in a Karo syrup medium. Digital microscopic images were made using the MetaMorph Imaging System running on a computer and receiving images from an Olympus BX60 microscope equipped with a Sony 3 CCD color video camera.

After scanning, Cranbury roots were dried at $105^{\circ} \mathrm{C}$ (dry weight determination) and ashed at $550^{\circ} \mathrm{C}$ to determine an indicative \% organic matter concentration. This was conducted because not enough root sample was available to determine $\mathrm{C}$ forms by more accurate methods.

The data collected from the above activities were used to calculate carbon accumulation in root biomass at the studied sites.

\section{Task 1b. Calculation of Carbon Gains}

Calculations of Carbon gains were conducted using the root density data and soil analytical data obtained from the task above and the following conversion parameters.

- Depth of rooting $=4.26 \mathrm{~m}(14 \mathrm{ft})$

- $\quad$ Backfill $=$ sand in the upper $1.8 \mathrm{~m}$ and organic backfill in 1.8-4.26 $\mathrm{m}$ depth

- $\quad$ Radius of casing $=0.3 \mathrm{~m}$ to $0.5 \mathrm{~m}$

- $\quad$ Backfill density $=2 \mathrm{~kg} / \mathrm{L}$

- $\quad$ Organic matter in deeper backfill $=3 \%$

- $\quad$ Root dry weight $=24 \%$

- Root organic matter $=90 \%$

- Organic matter $=2.56^{\circ} \mathrm{C}$

- $\mathrm{CO}_{2}=3.66^{\circ} \mathrm{C}$

- 500 trees per hectare

No attempt was made to calculate carbon losses via tree respiration, mineralization of root and backfill organic matter, or other; therefore, all data are referred to as "gross" carbon gains. Gross carbon gains were calculated under two different scenarios, in which the same growth was achieved in a temperate climate (where trees would integrate existing vegetation, rainfall is not a concern, and tree biomass production is already established) and in a sub-arid climate or a decertified area (where no existing vegetation is present and access to water would be the enabling factor for vegetation). 


\section{Task 2. Conduct Greenhouse Studies of Alternative Root Engineering Methodologies}

Previous efforts have demonstrated our ability to develop trees with elongated root systems up to $20 \mathrm{ft}$ long. This task focused on improving this methodology, increasing the root length and evaluating other rooting media that could either be utilized in the root elongation process and/or as backfill material to enhance Carbon sequestration in the deeper soil horizons.

Root elongation methodologies that are cost effective for larger-scale applications were tested as the current cost of planting is aimed at reclamation purposes and is targeted to maximize cost/benefits under a smaller field scale. Plants growing in the selected materials were periodically measured and checked for health and vigor.

Thirty-six plastic tubes, $4 \mathrm{~mm}$ thick and two meters long were filled with one of two soil types with 0,1 , or 3 cotton ropes extending the length of the plastic tubes. The filled tubes were coiled into the bottom of a 63 -liter bucket. The $63 \mathrm{~mm}$ rope consisted of cotton fiber casing with cotton stuffing.

The soil mixtures were prepared with varying amounts of peat, vermiculite, and sand. The two soil types, fine and coarse, were designated according to the percentages of each ingredient. The coarse soil mixture (designated F) consisted of 36\% peat, $51 \%$ vermiculite, and $12 \%$ sand. The fine soil mixture (designated C) consisted of 50\% peat, 33\% vermiculite, and $17 \%$ sand.

Eighteen willow trees and eighteen poplar trees were then planted in the plastic tubes inside the 63 liter plastic buckets. The 63 liter buckets were tagged according to four criteria: number of ropes $(0,1$, or 3$)$, type of soil mixture (c or f), tree type (poplar or willow), and repetition number $(1,2$, or 3$)$. Three repetitions of each trial were established for each treatment combination.

As the trees were planted into appropriate bags and tagged buckets, a line was drawn on the plastic tubing to mark the depth of the roots as they were planted. Also, one piece of drip tubing was inserted into each bag as a means to later water the plant. Soil was then backfilled and added to each system to the crown of each tree, approximately.

The trees were then placed in an incubation room, at 12-hour light cycle with a maintained temperature between $21-26^{\circ} \mathrm{C}\left(70^{\circ}-80^{\circ} \mathrm{F}\right)$. The trees were aligned in rows of four and an insulation board cover was placed over the tops of the 63-liter buckets to protect the roots from direct light.

The soil was relatively moist; however, an initial watering was performed. A four-liter container of water served as a reservoir for four plants. They were connected by means of drip tubing, which was inserted into the system previously.

On February 27, 2002 (on day 36), all trees were removed from the growth chamber and were analyzed for root elongation by uncoiling the tubing and measuring the visible root 
development. Additional marks were made at the root level for each tree. Root growth from initial planting was around $30+\mathrm{cm}$ depending on the tree.

One tree [Rope (1), Soil (f), Tree (w), and Repetition (2)] did not seem to be doing well, although root growth was comparable. Leaves were wilted and there was stem discoloration on its trunk. This tree was pruned accordingly. One week later (March 6, 2002), roots were harvested, roots washed from soil (Oliveira et al., 2000), and weighed fresh and dried at $105^{\circ} \mathrm{C}$.

Waste-derived amendments were evaluated for use as potential root elongation media and/or backfill material. A search for appropriate alternative materials was conducted and their composition studied so that appropriate amounts of nutrients and organic matter would be available. These materials would be mixed in formulations that (1) maximize carbon content without affecting plant growth and microbial competition for oxygen, (2) are sufficiently cohesive to allow the handling of elongated roots with no damage to plants, and (3) contain sufficient mineral calcium and/or magnesium in the oxide form to efficiently trap $\mathrm{CO}_{2}$ respired by the surrounding root/microorganisms.

\section{Results}

Task 1a. Investigate Root Density and Soil Conditions at Existing Sites

Soil boring samples were retrieved from sites where hybrid poplars had been planted at different times in the past and with different methodologies: while the Argonne site is approximately three years old and has cased and non-cased poplars, the Cantrall site is about 10 years old and has only non-cased trees. Cranbury, also a 10 year-old site, has only cased poplars. Poplar hybrids are the same at the three sites. Figures 2 to 9 illustrate the findings of the root density analysis. All results are also reported in a tabulated form in Tables 1 and 2.

In order to facilitate the understanding of the data, depth measures are reported in customary units (ft) while all other data is reported in SI units.

In general, root densities were not statistically different within depth at both Argonne and Cranbury (in cased trees), but statistically lower with depth at Cantrall (no casing). Argonne data from non-cased trees were insufficient for proper statistical analysis. Differences within distance from the tree center were, however, not statistically different $(\mathrm{P}=0.5)$ probably also because of the confounding effect of the ground cover and, in the case of Cranbury, because the tree roots had visibly escaped the casing at the surface.

The Argonne data (Figure 2) in general show that roots within the casing tend to be denser than the roots at the corresponding depth outside the casing and at the same distance from non-cased trees. No evidence of roots circumventing the casing at the soil surface was found during our field activities. In cased trees, rooting densities were sustained up to the maximum sampling depth (14 ft), and possibly deeper (it was not possible for us to obtain samples deeper than $14 \mathrm{ft}$ because of field equipment constraints). Outside the casing, no roots were found below the $7-8 \mathrm{ft}$ depth at $0.3 \mathrm{~m}$ from a non-cased tree, and below $5 \mathrm{ft}$ at $1 \mathrm{~m}$ from a TreeWell® 
cased tree. Surface samples also reflect the presence of a herbaceous cover that was relatively well developed throughout the site.

Poplars at Cantrall were planted in a backfill, which was in part made with the native soil, and were not restricted by the casing. Root growth (the trees' and also that of a healthy herbaceous ground cover) was found primarily only at the surface as reflected by rooting density data. Roots were measurable at a 3 meters radius from the tree at up to $6 \mathrm{ft}$ below ground (Figure 3). Ground cover at these sites was predominantly fescue grass and would clearly have an influence on the root mass found in the shallower samples taken 1 and 3 meters away from the tree. Unfortunately, a background sample of grass roots only was not available to try to distinguish their impact, as trees were not sufficiently spaced from each other to obtain a reliable control.

At the Cranbury location, where all trees were cased, root densities (both mass and length) were sustained all the way to the saturated zone (about $13 \mathrm{ft}$ ) (Figs. 4 and 5) and no differences in density was found with depth. Outside the casing, root densities were lower at all depths compared to analogous depths within the casing except for the 5 to $6 \mathrm{ft}$ depth samples. However, on visual observation roots of the poplars have been found escaping the casing from the surface. Mean root densities of up to $27-\mathrm{mg} / \mathrm{g}$ or $700-\mathrm{cm} / 100 \mathrm{~g}$ dry soil were found below $8 \mathrm{ft}$ in the subsoil.

To understand differences in the type of roots found at different depths in cased trees, and, therefore, differences in lignification, roots from the Cranbury site were scanned before drying and the scanned image processed using a specialized software (WinRhizo, Regents Instruments). Root length data, as well as root length partitioning in three diameter classes ( 0 to $0.5 \mathrm{~mm}, 0.5 \mathrm{~mm}$, to $2 \mathrm{~mm}$, and greater then $2 \mathrm{~mm}$ diameter) were obtained. Results are found in Figure 6 and Table 2. On average, about 71\% of the root length was found in the smaller diameter roots, $26 \%$ in the intermediate class, and approximately $2 \%$ of the total root length was found in roots larger than $2 \mathrm{~mm}$ in diameter. These proportions were sustained throughout the soil profile with no clear differences attributable to depth, indicating, therefore, that ratios of lignified versus fine roots at depths could be similar to what found in the surface soil layers.

The morphology of shallow (0-1 m) and deep (3.5-4 m) roots of hybrid poplar trees growing at the Cranbury site was also compared at the light microscope level. Cross sections of roots showing the findings are found in Figures 7-9.

The roots examined in this study are in an early stage of secondary growth. The secondary tissues of a root are similar to those of a stem. The original root cortex tissue is usually crushed near the root periphery by the expanding secondary phloem. Cork cambium arises in the secondary phloem and forms a dark-colored, multi-layered periderm or bark on the outside of the root that replaces the epidermis. In the root secondary xylem, vascular rays are generally larger and more abundant than in stems. The xylem cylinders of both the shallow and deep roots were similar, with little distinction between the primary and secondary xylem at the center of the cylinder. In the secondary xylem, large xylem vessels are uniformly distributed throughout a matrix of much smaller xylem fibers. In some cases in the shallow roots, the lumen 
of the vessels in the center of the root were filled with a dark material. This condition was not observed in the deep roots.

The tissues outside the central cylinder of primary and secondary xylem in both the shallow and deep roots consist of the cambium, secondary phloem, cortex (probably crushed), and the periderm. The secondary phloem contains mostly parenchyma cells, but also contains the sieve elements, which conduct metabolites downward from the leaves and are not particularly evident in these roots, and scattered highly birefringent bundles of thick-walled phloem fibers. The phloem fibers are primarily structural in nature, providing rigidity and support to the thinwalled phloem parenchyma tissues. In both shallow and deep roots fixed in FAA, the periderm is somewhat brittle and often shatters or curls when hand sections are made.

The most obvious differences between the shallow and deep roots were found in the morphology of the aerenchyma tissue. Aerenchyma is found in the roots and stems of many plants, and consists of secondary phloem parenchyma cells with interconnected air spaces between the cells that provide a pathway for the exchange of gases, both atmospheric and those generated within the plant. The aerenchyma tissue in the roots of willows has been shown to provide a continuous pathway for atmospheric oxygen and other gases to reach respiring tissues in the roots that are growing in oxygen-deficient soil conditions, or where the roots have been inundated by groundwater (Kawase and Whitmoyer, 1980). The oxygen is taken in through lenticels in the branches, fissures in the bark, and stomates in the leaves. In the deep roots, we found that these areas are large, have a sponge-like appearance, and sometimes comprise most of the phloem parenchyma. In the shallow roots, the areas of aerenchyma are smaller with fewer large air spaces, and are usually restricted to a layer just outside the xylem and around some of the phloem fiber bundles (see Figures 7 and 8).

In the shallow roots, the entire area outside of the xylem cylinder appears more organized and has a more complex structure than in the shallow roots. The phloem fiber bundles are more numerous and distributed throughout the phloem parenchyma. The vascular rays are obvious as they pass from the xylem, through the relatively narrow band of aerenchyma, and into the more dense area of the phloem where they can be traced almost to the periderm.

In the deep roots the area outside the xylem appears to be less complex than the shallow roots because much of the area is composed of spongy aerenchyma tissue. Directly adjacent to outside of the xylem is a disordered layer of very small cells in the location of the cambium. This irregular cambium may account for the more disorganized appearance of the deep roots. The phloem fiber bundles are fewer in number and tend to be restricted to the outer periphery of the large spongy aerenchyma areas. The vascular rays are not as evident in both the xylem and phloem of the deep roots.

Round granules found at the iodine test to be amyloplasts containing stored starch were observed in most of the phloem parenchyma cells, including the aerenchyma cells, of both the shallow and deep roots. However, the granules in the deep root parenchyma cells tended to be larger and greater in number than those in the shallow roots (see Figure 9). 
In the hybrid poplars at the Cranbury site, the planting techniques resulted in roots growing so deep that little or no atmospheric oxygen penetrates through the soil to the roots. In addition, free-living microorganisms compete with the deep roots for any available oxygen in the soil solution, thus depleting it even more. The large volume of aerenchyma in the deep roots may provide sufficient oxygen to permit relatively normal growth at depths well over 4 meters. Because of reduced oxygen levels, and lower temperatures, it is hypothesized that carbon sequestered as root biomass at these depths will have much longer turnover times.

Soil analysis data are reported in Table 3. Organic matter at the Argonne site reflects the composition of the backfill: slightly but statistically significantly lower $(<1 \%)$ in the first $6-7 \mathrm{ft}$ from surface, where sand was used to discourage rooting near the surface, and 3 to $3.5 \%$ at depths below $7 \mathrm{ft}$. Nitrate was found heterogeneously throughout the soil column and sharply reduced at depths outside the casings. Phosphate was found significantly higher $(\mathrm{P}=0.04)$ at lower depths (again as a result of the richer backfill).

At the Cantrall site, where native soil was used to backfill the non-cased trees, organic matter was significantly $(\mathrm{P}=0.03)$ higher $(2 \%)$ in the first $3 \mathrm{ft}$ than below, where it decreased to negligible levels. The soil tended to be more alkaline with depth (NS) and P was significantly higher $(\mathrm{P}=0.07)$ at the surface at all distances from the tree center. Nitrate, present as a contaminant in the groundwater, was significantly higher $(\mathrm{P}=0.06)$ in deeper soil samples regardless of their radial distance from the tree center.

Organic matter at Cranbury was in general slightly higher at the surface but generally below or equal to $1 \%$ throughout the cased column. No differences were found within the casing and outside of it (native soil was used to backfill). Like the Cantrall case, the higher nitrate concentrations found at depth reflect the effects of the contaminated groundwater. $\mathrm{P}$ and $\mathrm{pH}$ were homogeneous throughout the profile.

Respiration Experiments were intended to provide a comparative measure of microflora in the different samples by determining rates of $\mathrm{CO}_{2}$ evolution under constant, unlimited oxygen supply at ambient temperature. Results are reported in Table 4. They were not be used to draw conclusions on actual respiration below ground as oxygen and temperature may be limiting factors of which no actual prediction was inferred by these studies. The only significant comparison $(\mathrm{P}=0.08)$ was found in the Argonne soils where the increased respiration of the deeper soil vs. the surface reflects the fact that sand was used as a fill for the first 6-7 $\mathrm{ft}$ from surface, and organic-rich topsoil for depths below $7 \mathrm{ft}$. Chemical analysis data also support this finding. Respiration was also found to be higher outside the casing, although with a lower $\mathrm{P}(0.6)$. Soils from other sites did not show appreciable differences in respiration rates based on original depths of the samples or radial distance from the tree centers.

\section{Task 1b. Calculate Carbon Gains}

Gross carbon gains are summarized in Table 5. The data obtained from the previous task were applied to two different scenarios to determine benefits in carbon gain from the studied technology. 
In the case of a temperate climate planting, where vegetation is normally present, comparative carbon gains may be more limited in quantity and mostly reflect the better stability of the water supply. While an increase of total biomass compared to the "current" condition may be expected based on luxury consumption of water, the biggest comparative gains would derive from the removal from the surface of large amounts of organic backfill, which would be partly shielded from rapid mineralization in the deeper, cooler, and oxygen-limited soil strata. Not included in our estimate are benefits derived from reduced competition with herbaceous vegetation for water, nutrients, and space, and the reduced mineralization at depths due lower temperatures and limited oxygen availability. Also, the composition of the backfill can be efficiently manipulated to include sufficient amounts of $\mathrm{Ca}$ and $\mathrm{Mg}$ oxides in granular form to "trap" the respired $\mathrm{CO}_{2}$ thus sequestering it more permanently in the subsoil. The maximum amount of these compounds would actually be determined by the plant specific tolerance to subalkaline soil conditions.

On the other side, carbon gains in areas where no vegetation is currently growing because of limited access to water could be significant. In this case, any biomass gain (both above and below ground) would be an improvement from the "current" condition where no vegetation is present and the surface soil is typically exposed to erosion, elevated temperatures, and rapid mineralization of the already minimal organic matter present.

Promoting deep rooting at these locations could serve the dual purpose of (1) enabling the plant survival and growth altogether by providing access to water, and (2) localizing root biomass and backfill away from the surface and into the more protected, cooler and oxygen poor subsoil. While we could not determine information on annual accumulation of carbon, $\mathrm{CO}_{2}$ gross accumulation estimated for the two-year Argonne plantation was 12 tons, while estimates from the 10-year old Cranbury site were 42 ton. $\mathrm{CO}_{2}$ in root mass "normalized" to reflect one-year growth at the ANL and Cranbury sites could be on the order of 4 to 6 tons per year per hectore.

\section{Task 2. Conduct Greenhouse Studies of Alternative Root Engineering Methodologies}

Root elongation methodologies that are cost effective for larger-scale applications were tested. In particular, attention was given to techniques that would minimize the volumes of backfill substrate (hence, the diameter of the borehole that is necessary for planting) and at the same time offer the adequate capacity for water and nutrient to provide self-sustainability until the roots reach the groundwater. As indicated before, this study was term limited by the timing conflict between the initiation of the SBIR (late August) and the availability of trees from nurseries (November-December). Results are summarized in Table 6.

Results to date indicate that after a period of acclimation, root elongation can occur fairly quickly $(>1.0 \mathrm{~cm} /$ day and greater once elongation is initiated - roots have previously been observed to develop 3-5 cm in a single day). Rapid elongation occurs at an interface such as the soil and the casing where fewer restrictions are encountered.

The addition of the cotton rope as a conduit seemed to benefit poplar tree root development in the finer textured soil; otherwise, there were no other treatment differences noted 
within the time allowed for this study. It would appear that rooting could readily occur with less substrate than currently utilized as long as there is a physical pathway and a reserve of moisture along that pathway (so trees can be planted with wet backfill and left unirrigated). At a field scale, roots would follow this pathway and utilize that moisture to get to the deep groundwater.

The rope was, however, effective at improving the handling conditions of the growing tube, providing a tensile structure to support the relatively heavy weight of the columnar rooting medium, thereby decreasing the potential for breaking the fragile, turgid root developing inside.

Roots will follow a conduit downwards, with minimal theoretical dispersion of nutrients, which are therefore less available for microbial life away from the immediate rhizosphere (thus, less respiration by microorganism, more oxygen available for root use). This conduit is also fundamental in providing mechanical strength to the root column thus protecting it from breaking during manipulation.

The amount of substrate (rooting medium) can then be adjusted based on its water and nutrient storage properties without significant impact on mechanical support for the growing root.

A series of alternative backfill materials were selected for further study that would at the same time maximize carbon sequestered in the subsoil, minimize non-renewable, traditional substrates like peat, have excellent water holding characteristics, and be sufficiently cohesive to ensure practical handling.

Waste-derived amendments evaluated for use as potential root elongation media and/or backfill material include:

- Peat substitutes: yard waste compost, biosolids.

- $\mathrm{CO}_{2}$-trapping materials: sand slag, (an alternative to calcium oxide).

The chemical composition of these materials was researched (Table 7) and a possible formula that would closely match that of conventional, non-renewable backfills made of peat, topsoil, and fertilizers could be developed. All the materials proposed have been previously tested for their compatibility for plant growth and do not contain environmentally harmful contaminants in concentrations that would be of concern.

By utilizing yard waste compost and biosolids, approximately 70-100 cubic meters per hectore could be removed from the surface and deposited in the subsoil where they would mineralize at slower rates.

\section{Conclusions}

While the data collected from the field activities still provides limited information, a few conclusions can be drawn that support further research and development of this technology.

A clear difference in root densities at varying depths based on the presence or absence of a casing (the TreeWell ${ }^{\circledR}$ liner that directs roots downward) was found in field samples. Where 
there was no casing directing the roots, the rooting activity was focused near the surface and was developed at a greater distance from the tree center.

Data from older installations like Cranbury show that root densities within the casing at 3-4 meters depth can be comparable in quantity and quality to the density at $30 \mathrm{~cm}$ depth. Root distribution by diameter size in the deeper samples was also found to be similar to that at the surface, having a comparable amount of lignified and larger diameter roots.

Roots growing at 4 meters depth were substantially different than those at the surface. The morphological traits differed in the presence and abundance of aerenchima, indicating that oxygen levels at this depth are probably barely sufficient for root metabolism and development. Conversely, this would indicate that microbial respiration would suffer due to the low oxygen levels predicted and suggested by the morphology of the roots.

Clear carbon sequestration benefits can be envisioned in two distinct scenarios: In the case of temperature climate, gains would be mostly derived from the storage of carbon-rich substrate at depths where respiration is minimized. Additional carbon gains would also come from deeper rooting and reduced turnover of roots growing in cooler and oxygen poor subsoil at depths.

The most significant carbon gains could however be obtained when these technologies are applied to establish vegetation in semi-arid areas where no vegetation is currently present. In these cases, by enabling a vegetative growth altogether, significant benefits in $\mathrm{CO}_{2}$ trapping could be achieved.

The addition of high organic matter substrates to the backfill of deep rooted trees can make a significant difference in the $\mathrm{C}$ balances, in terms of using "renewable" materials instead of "non renewable" peat.

Future work could expand these planting and rooting techniques to additional plant species providing substantial innovation in fruit and hard wood crops. 


\section{References}

Argonne National Laboratory-East, Remedial Action Project (1999). "Construction Report for the 317 Area French Drain Phytoremediation Project." (SWMU No. 11), ANL-D317-113-F-T01-0.

Canadell, J, R.B. Jackson, J.R. Ehleringer, V.A. Mooney, O.E. Sala, and E.D. Schulze (1996). Maximum Rooting Depths of Vegetation Types at the Global Scale. Oecologia 108:583-595.

Gatliff, E.G., et al. (1998). Uptake and Fate of Organohalogens by Woody Plants. Proceedings $1^{\text {st }}$ International Conference on Remediation of Chlorinated and Recalcitrant Compounds, Monterey, CA, May 18-21, 1998.

Kawase, M., and R.E. Whitmoyer (1980). Aerenchyma Development in Waterlogged Plants. Am. J. Bot. 67:18-22.

Lal, R. (2000). Carbon Sequestration in World Soils. ENERGEX 2000 Publications, Oak Ridge National Laboratory, TN.

Nyer, E.K., and E.G. Gatliff (1996). Phytoremediation. Ground Water Monitoring and Remediation 16(1):58-62.

Oliveira, M.R.G., M van Noordwijk, R.S. Gaze, G. Brouwer, S. Bona, G. Mosca, and K. Hairiah (2000). Auger Sampling, Ingrowth Cores, and Pinboard Methods. In Root Methods, a Handbook, A.L. Smit, A.G. Bengough, C. Engels, M van Noordwijk, S. Pellerin, and S.C. van de Geijn, eds., Springer Verlag, Berlin, p. 191.

Quinn, J.J., M.C. Negri, R.R. Hinchman, L.M. Moos, J.B. Wozniak, and E.G. Gatliff (2001). Predicting the Effect of Deep-Rooted Hybrid Poplars on the Groundwater Flow System at a Large-Scale Phytoremediation Site. Int. Journal of Phytoremediation

Smith, S.D., D.A. Devitt, A. Sala, J.R. Cleverly, and D.E. Busch (1998). Water Relations of Riparian Plants from Warm Desert Regions. Wetlands, Dec. 1998, 18,4, pp. 687-696.

U.S. Department of Energy, Offices of Science and Fossil Energy (1999). Carbon Sequestration Research and Development. Washington, DC.

Waisel, Y., A. Eschel, and U. Kafkafi (eds.) (1996). Plant Roots - The Hidden Half. Marcel Dekker, Inc., NY.

Zibilske (1994). "Carbon Mineralization." In Methods of Soil Analysis, Part 2. Microbiological and Biochemical Properties. Weaver, R.W., S. Angle, P. Bottomley, D. Bezdicek, S. Smith, A. Tabatabai, A. Wollum, eds., Soil Science Society of America, Inc. 


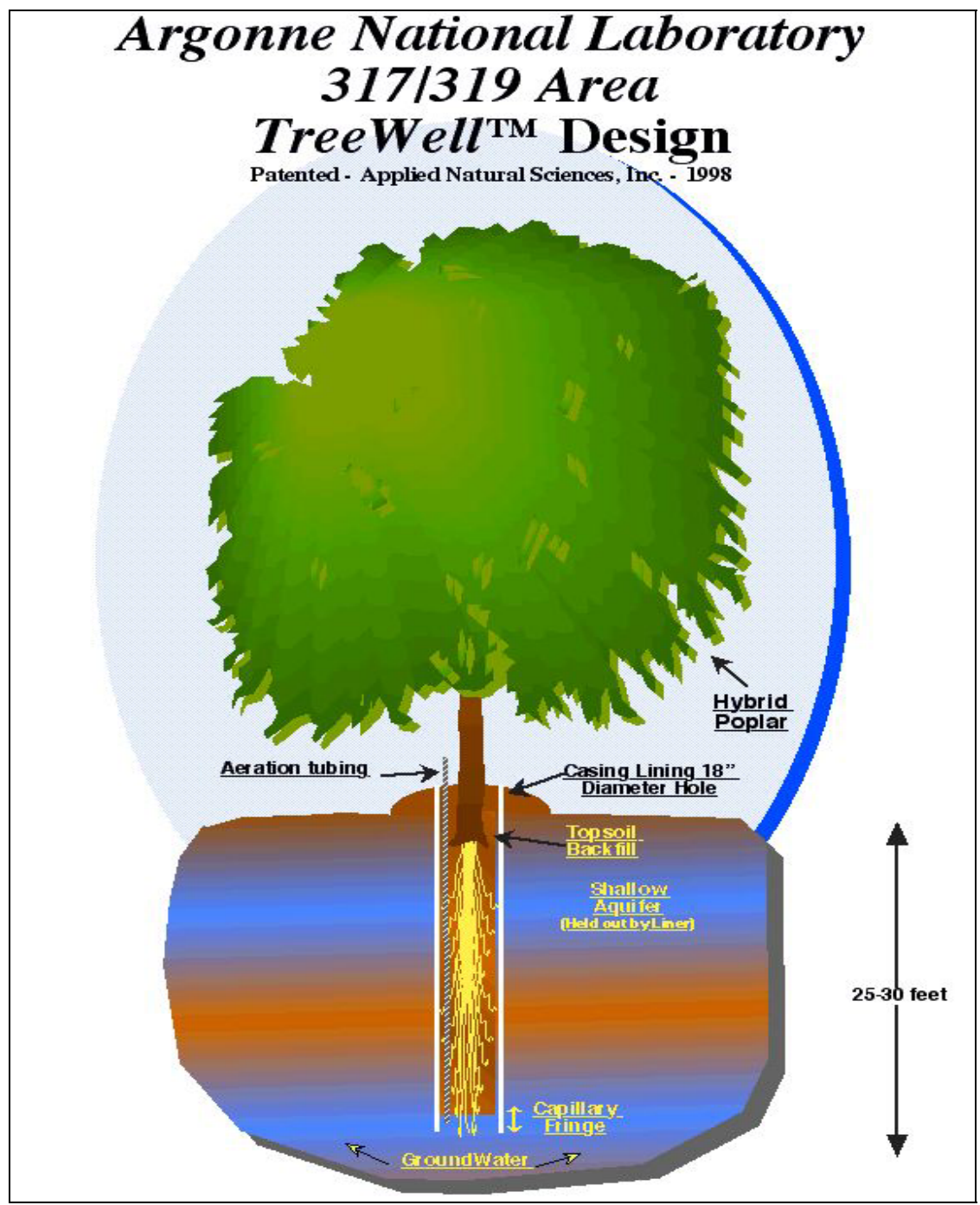

Figure 1. Diagram of TreeWell ${ }^{\circledR}$ root-engineering method. An impermeable liner insulates growing roots from surface soil moisture to promote deep root growth to reach the groundwater; appropriate backfill materials inside the liner are used to direct root growth where desired. 


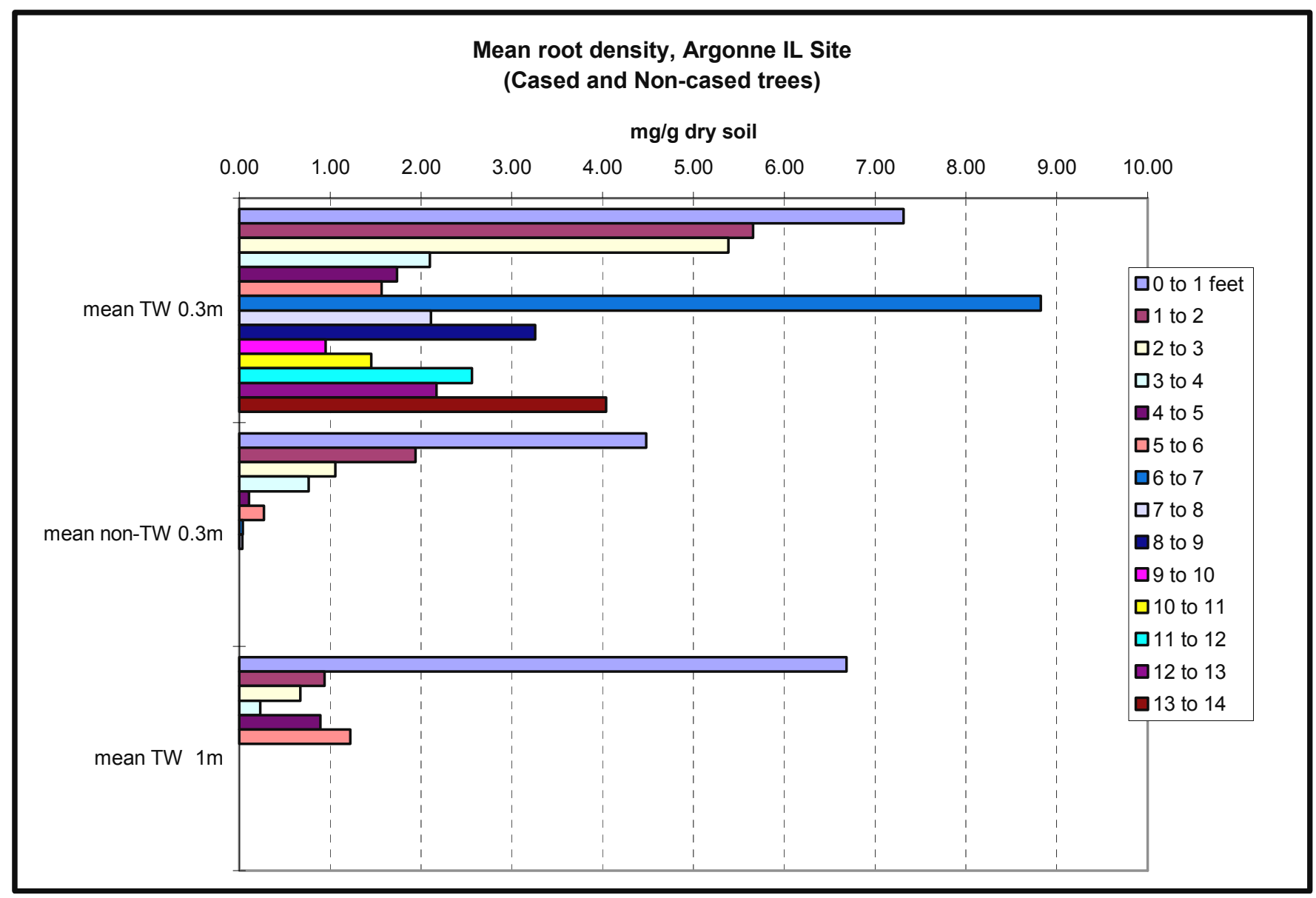

Figure 2. Mean root density (mg fresh root per g dry soil) inside the TreeWell ${ }^{(T W}$ ) casing, outside the casing and at $0.3 \mathrm{~m}$ of a non-cased tree, Argonne site. 


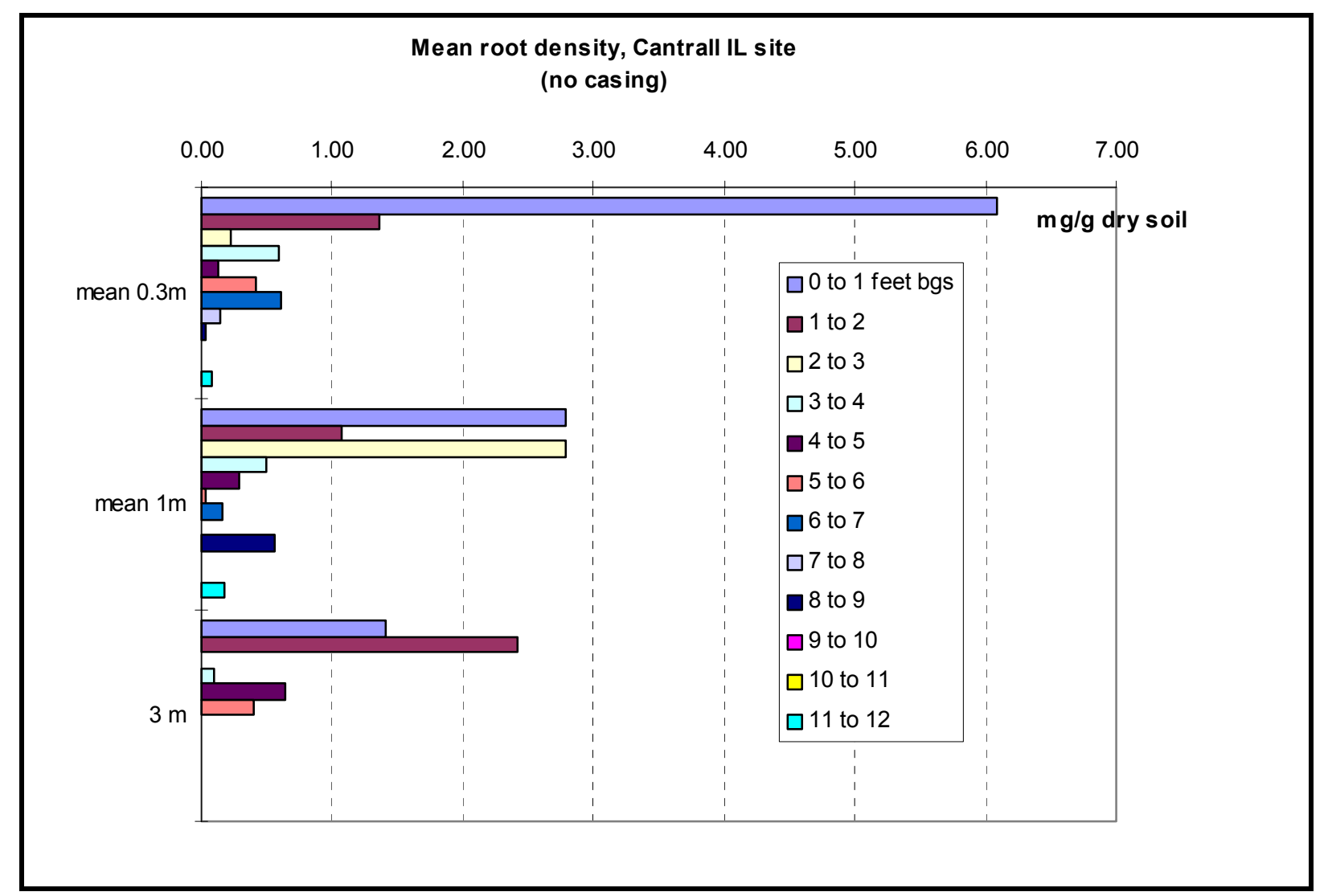

Figure 3. Mean root density ( $\mathrm{mg}$ fresh root per g dry soil) in non cased poplars at $0.3,1$, and $3 \mathrm{~m}$ from tree center. Mean of three replications, Cantrall site. 


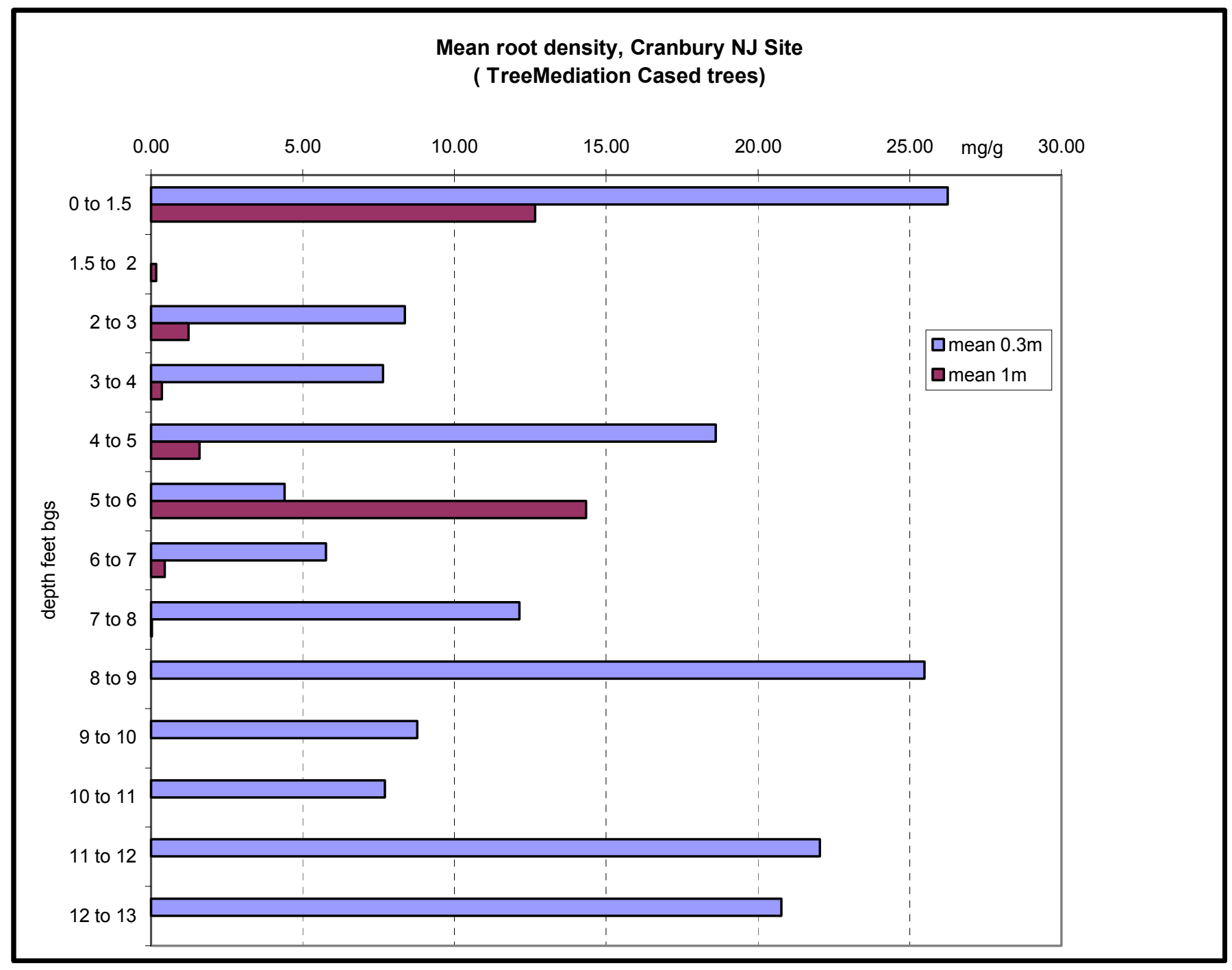

Figure 4. Mean root density (mg fresh root per $\mathrm{g}$ dry soil) in the fill material inside the TreeMediation ${ }^{\circledR}$ casing $(0.3 \mathrm{~m})$ and outside $(1 \mathrm{~m})$. Data are mean of three replications, Cranbury site. 


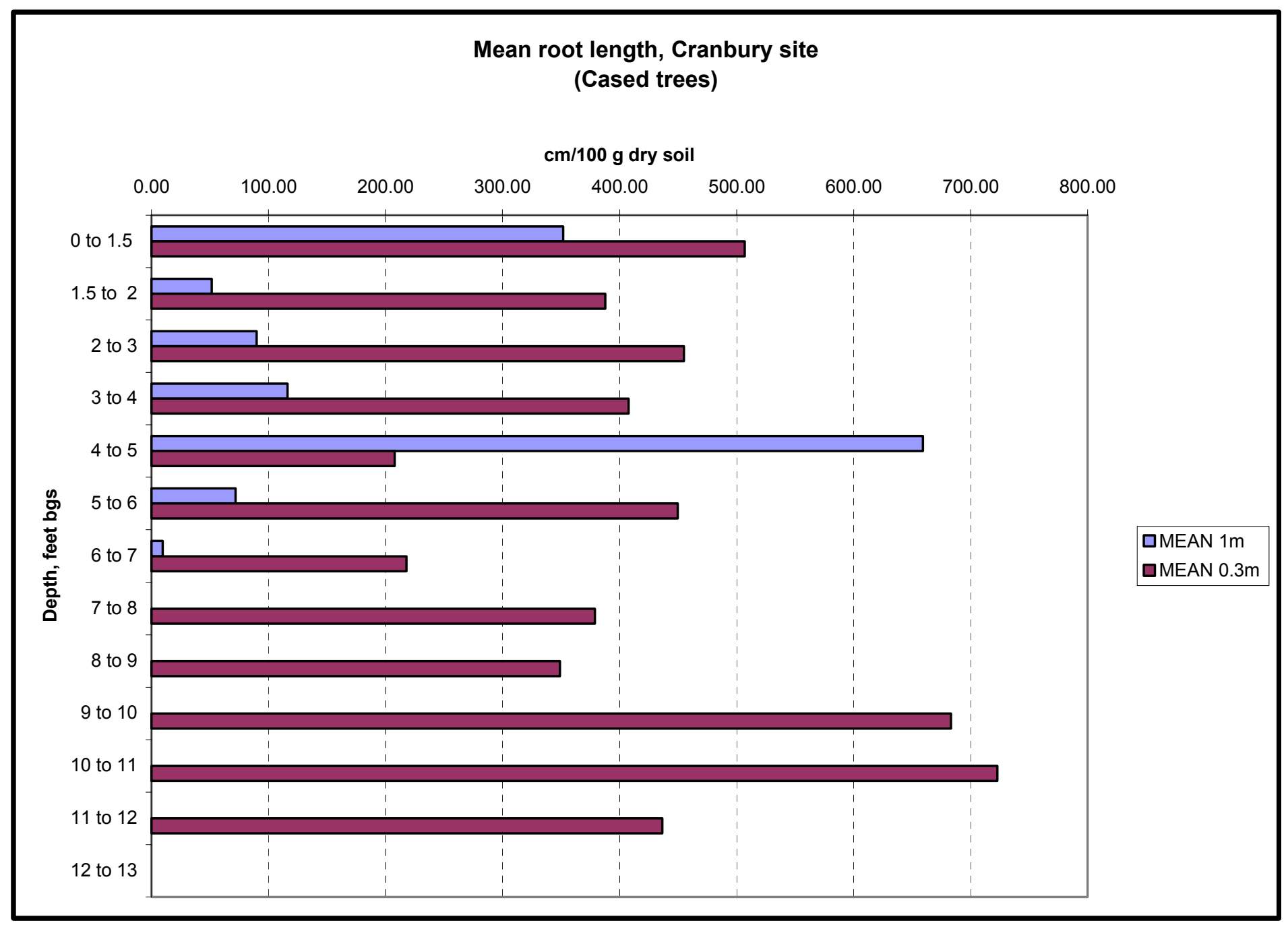

Figure 5. Mean Root length $\left(\mathrm{cm} / 100 \mathrm{~g}\right.$ dry soil) inside $(0.3 \mathrm{~m})$ and outside the TreeMediation ${ }^{\circledR}$ casing. Data are mean of three replications, Cranbury site. 


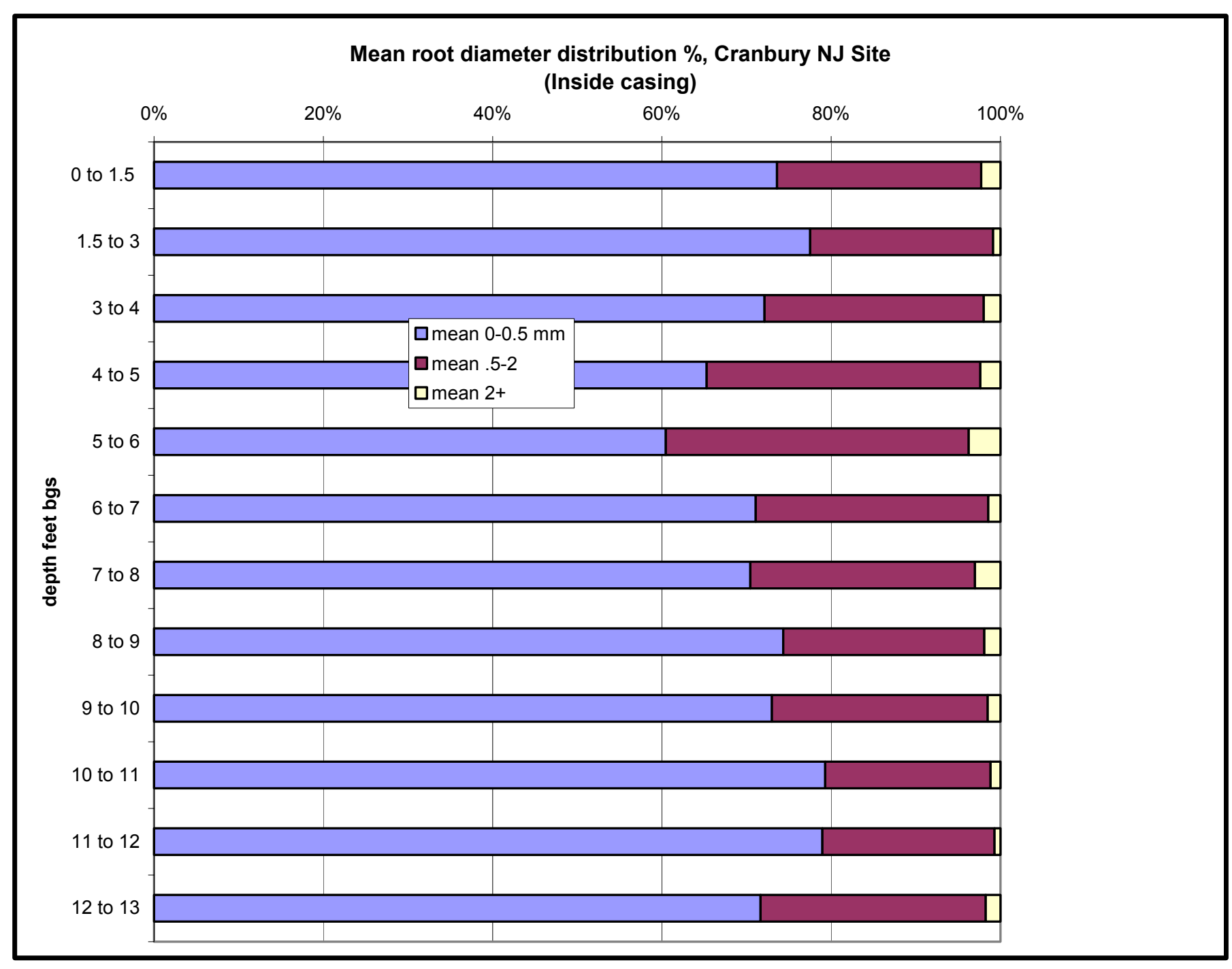

Figure 6. Mean root length distribution in three diameter classes in the fill inside the TreeMediation ${ }^{\circledR}$ casing, Cranbury site. 


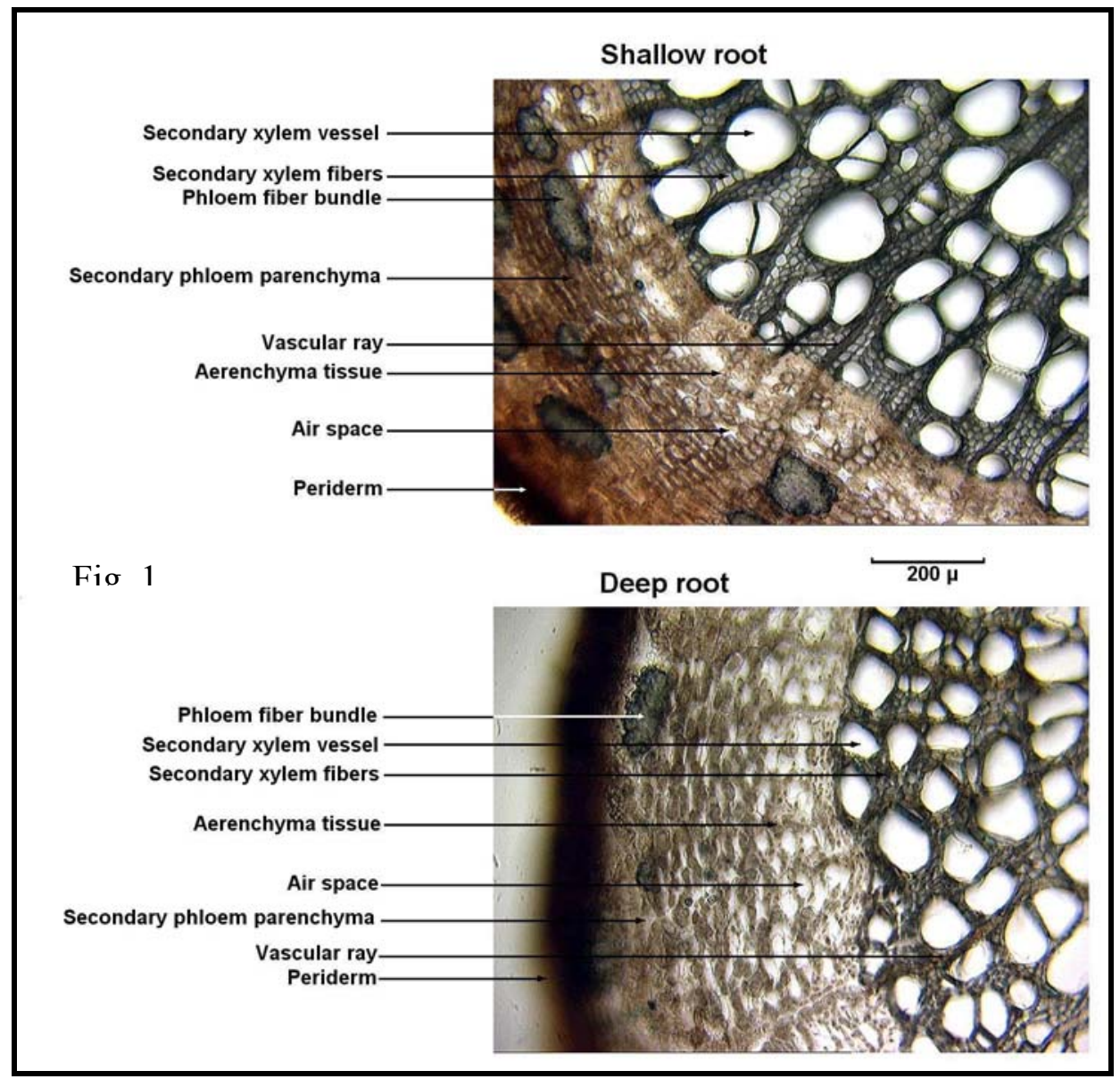

Figure 7. Cross sections of a shallow and deep root of hybrid poplar showing the periphery of the secondary xylem cylinder on the right and the secondary phloem tissues on the left. The periderm forms the outer periphery of the root. Note the relatively narrow band of aerenchyma in the shallow root, while aerenchyma comprises most of the phloem in the deep root. 


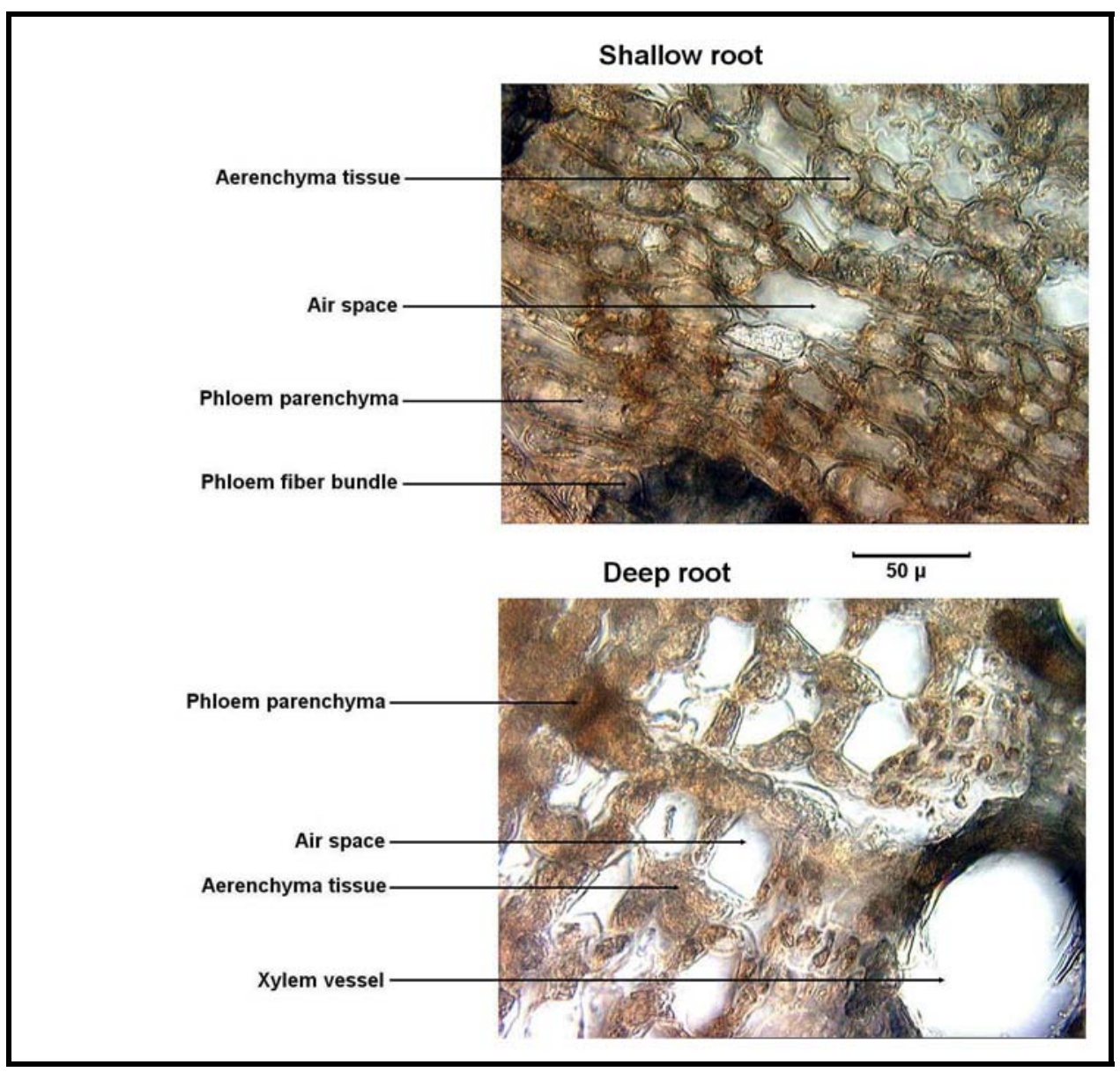

Figure 8. Cross sections of a shallow and deep root of hybrid poplar showing a portion of the aerenchyma tissue of each. The shallow root has a relatively narrow band of aerenchyma with small air spaces, while the extensive aerenchyma of the deep root is sponge-like with large air spaces. 


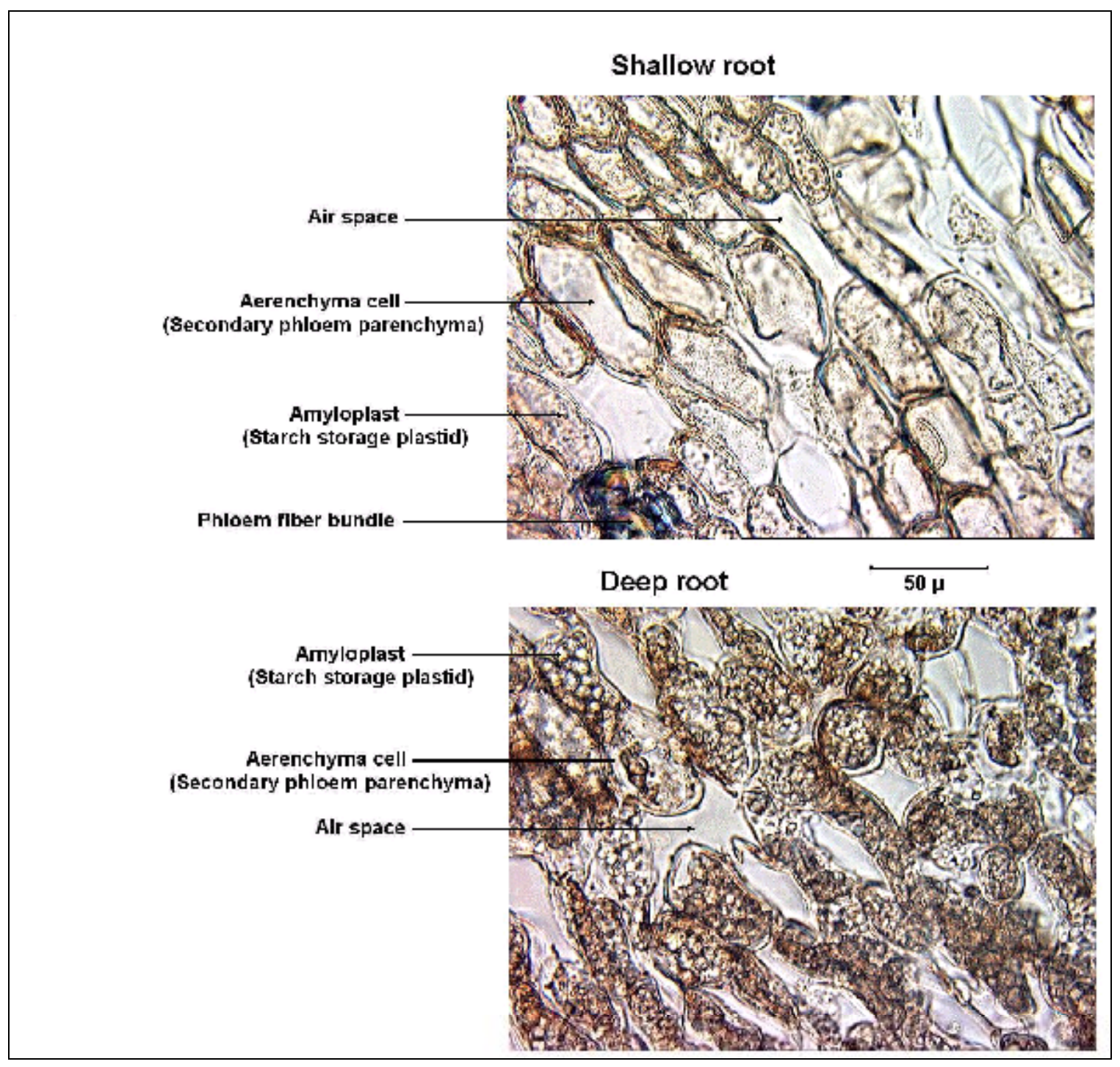

Figure 9. Aerenchyma tissue in cross sections of shallow and deep roots of hybrid poplar showing amyloplasts (starch storage plastids) inside the cells. Note that the amyloplasts in the aerenchyma cells of the deep root are larger and more numerous than those in the shallow root aerenchyma cells. 
Table 1. Root Mass Density Report.

Table 2. Cranbury Root Length Report

Table 3. Soil Analysis Report

Table 4. Respiration Study Results.

Table 5. Gross Carbon Gains.

Table 6. Root Elongation Study Results.

Table 7. Composition of Alternative Backfill Materials. 
Appendix: Statistical Analysis Reports 